\title{
Como chegamos a este ponto?
}

\section{How Did We Get to This Point?}

Juliana da Costa Gomes de SOUZA*

Obra resenhada:

WORSTER, Donald. Shrinking the Earth: The Rise and Decline of American Abundance. London: Oxford University Press, 2016. 279p.

Shrinking the Earth, "Encolhendo a Terra", em tradução livre, é a produção literária mais recente do historiador ambiental Donald Worster, que nasceu em 1941 e cresceu em Hutchinson, Kansas. Na década de 1970, ele se tornou mestre em filosofia pela Yale University e doutor em História pela mesma universidade. A partir de 1989, ocupou a cadeira de História Norte-americana da University of Kansas. Após sua aposentadoria, em 2012, Worster se tornou especialista estrangeiro e professor sênior da escola de História da Universidade Renmin, China. Ele é um dos fundadores da história ambiental norte-americana e foi presidente da American Society for Environmental History. Durante sua carreira, escreveu livros que influenciaram o campo da disciplina, como A River running West: the Life of John Wesley Powell (2000) e A Passion for Nature: the Life of John Muir (2008).

A História Ambiental pretende entender como ambiente e sociedade se relacionam. A disciplina surgiu em meados de 1970, predominantemente

\footnotetext{
* https://orcid.org/0000-0001-9713-1629

Universidade de Brasília, Centro de Desenvolvimento Sustentável

Campus Universitário Darcy Ribeiro, 70910-900, Brasília, DF, Brasil

jcgdesouza@gmail.com
} 
na Europa e nos Estados Unidos da América (EUA), quando cientistas naturais apontaram consequências danosas da ação humana sobre a natureza. Essa nova percepção de estudo enfrentou, e ainda enfrenta, resistência das Ciências Humanas, embasadas no paradigma durkheimiano, no qual o social se explica apenas pelo social. Worster dialoga nesse livro com a noção de fronteiras e limites, trabalhados pelos historiadores norteamericanos Frederick Jackson Turner (1861-1932) e Walter Prescott Webb (1888-1963). A obra resenhada trata da história ambiental mundial e busca explicar como chegamos à atual situação planetária, marcada cada vez mais pela escassez de recursos, pontuando questões importantes para o estudo da sustentabilidade. O livro está dividido em três partes, além do prólogo e epílogo. Cada parte é composta de três capítulos narrativos e de um quarto capítulo referente a uma viagem de campo.

No prólogo "Luz Verde de Gatsby", o autor utilizou uma passagem do romance de Francis Fitzgerald (1896-1940), The Great Gatsby (1925), para delinear uma visão alternativa do passado de devastação da natureza e guiar a leitura. A passagem se refere aos momentos em que Gatsby, um emergente social romântico e sonhador, enxerga uma luz verde à distância no porto e fica esperançoso de ser aceito pela rica Daisy Buchanan. A luz apenas assinala o ancoradouro da mansão de Daisy, mas simboliza as expectativas de Gatsby em relação ao seu futuro. Essa luz verde também representa as expectativas de crescimento da já próspera sociedade estadunidense de 1920. Worster chamou de "teoria da luz verde" a ilusão que os humanos têm de um futuro em que a natureza seja sempre abundante.

Ainda no prólogo, Worster avisa que abandonou três perspectivas familiares na história contemporânea: da simpatia pelos perdedores, da escola dos bons hábitos e das boas instituições e da continuidade do Holoceno. Sobre as duas primeiras, Worster afirma que trata dos êxitos na extração de matérias-primas da natureza, principalmente os referentes à colonização dos EUA. Sobre a terceira visão, ele aponta que alguns cientistas já consideram que estamos no Antropoceno, uma era de grandes transformações causadas na biosfera pelo ser humano, principalmente a partir da Revolução Industrial do século XVIII. A era anterior, 
o Holoceno, iniciada há doze milênios e pós período de glaciação, teve sua relativa estabilidade da natureza abalada justamente pela atuação humana.

Na parte I, Worster descreve as revoluções que ocorreram na sociedade europeia após o descobrimento do Novo Mundo pelos colonizadores europeus. Eles conseguiram expandir suas fronteiras e promover o desenvolvimento utilizando recursos naturais obtidos de suas colônias, mas mesmo alguns dos primeiros economistas advertiram que o crescimento econômico e social tinha um limite. O inglês John Stuart Mill (1806-1873) foi o primeiro a dizer que essa limitação não era necessariamente ruim, pois impunha novos desafios ao estilo de vida europeu (1848). Além disso, para Mill nem tudo do mundo natural podia ser precificado ou utilizado, ideia semelhante à dos primeiros defensores da natureza selvagem, ou wilderness, como William Wordsworth (1770-1850) e Henry David Thoreau (1817-1862). Worster finaliza a primeira parte descrevendo a caça desenfreada às baleias na ilha de Nantucket na metade do século XIX, o que levou à quase extinção do animal.

A parte II, "Depois da Fronteira”, narra uma sequência de práticas de extração de recursos naturais nos EUA, as suas consequências e os estudos feitos pelo conservacionismo norte-americano, encabeçado por George Perkins Marsh (1801-1882). É descrito o poder destrutivo da agricultura, que desequilibrava ciclos d'água. A crise hídrica foi tema da viagem de campo, que trata do "Vale Imperial", na Califórnia, estado que passou por uma grande seca em 2003. A devastação continuou por meio do desenvolvimento industrial do século XIX, quando o combustível propulsor da indústria, o carvão, levou à contaminação do ar, solo e da água por substâncias tóxicas, alterando o ciclo do carbono. Combinado com o ferro, o carvão proporcionava a criação do aço, que passou a ser utilizado nas ferrovias, amplificando a expansão das cidades e a destruição ambiental. Com a escassez do carvão, o gás natural e o petróleo se tornaram os próximos combustíveis das atividades humanas. Essa grande dependência dos recursos naturais e como lidar com ela é descrita na sequência. O presidente Theodore Roosevelt (18581919) tentou associar o conservacionismo aos interesses industriais, o que foi desastroso para o meio ambiente. Para Roosevelt, a construção 
de barragens, por exemplo, significava transformar um "desperdício" de força d'água em lucro para a sociedade. Atualmente, essa associação falaciosa fica explícita em empresas que utilizam o prefixo "eco" em seus produtos, sem praticar qualquer forma de proteção à natureza.

Após tanta devastação, chegamos ao limite, tema da terceira parte do livro. A narrativa inicia com a fase posterior à Segunda Guerra Mundial nos EUA, que se caracterizou pelo aumento do consumismo e desenvolvimento desenfreado, incomodando até mesmo os conservacionistas mais adeptos da prosperidade econômica. Surgiu, então, uma categoria mais prática de conservacionistas, a dos ambientalistas modernos, que comprovaram como a ação exploradora humana acarretava na degradação do meio ambiente. ${ }^{1}$ Worster dispende boa parte dos capítulos seguintes discorrendo sobre a obra dos cientistas Dennis Meadows e Donella Meadows (1941-2001), autores principais de The Limits to Growth (1972). O livro foi um alerta sobre as dinâmicas do sistema social, seus limites e a necessidade de ajustes para que o mundo não colapse. A partir desse estudo, outros pesquisadores começaram a delimitar uma zona de perigo relacionada à capacidade de suporte da Terra. A viagem de campo, "Rio Athabasca" (Canadá), encerra a terceira parte. O betume descoberto no rio canadense, localizado em uma floresta boreal, tinha extração e tratamento difíceis e onerosos. Após a crise do petróleo em 1973, investiu-se desesperadamente em sua extração e área e o rio ficaram devastados.

No epílogo, "Vida em um pálido ponto azul”, Worster cita a viagem ao espaço da Voyager I, em 1977. O astrônomo Carl Sagan (1934-1996) pediu que fosse fotografado o que havia ao redor da nave. Foi registrada apenas a Terra, um pálido ponto azul. O Novo Mundo esperado pela ida do homem ao espaço não existe. Worster propõe que é preciso aprender a viver com os recursos disponíveis. Ele alerta que, por conta do crescimento da tecnologia, da população e do consumo, o nosso mundo está encolhendo ecologicamente. A lógica da composição do livro se completa: descoberta, exploração e limites.

1 Para melhor compreensão das categorias de proteção da natureza, sugiro NASH, 1990. 
Worster expõe a sua preocupação principal com a devastação ambiental desde o primeiro capítulo do livro e a reitera ao longo de sua narrativa: "Mas quais são as chances de encontrar outra natureza, outro hemisfério de abundância tão fácil? Zero”2 (p. 25). Apesar do livro ser definido como de História Ambiental global, Worster concentra sua narrativa na Europa e nos EUA, o que não desvirtua a proposta da obra. Sua riqueza de informações a torna acessível a qualquer pessoa que tenha interesse em compreender o "encolhimento" da Terra, situação explícita a quem se propõe observar minimamente as condições em que se encontra o meio ambiente. Shrinking the Earth não se desenvolve em tom alarmista, mas não deixa de ser um alerta sobre a situação atual e futura da Terra e seus habitantes: não temos mais um longo passado pela frente.

\section{REFERÊNCIAS BIBLIOGRÁFICAS}

FITZGERALD, Francis Scott. The Great Gatsby. New York: Charles Scribner's Sons, 1925.

MEADOWS, Donella H. et al. The Limits to Growth: a Report for the Club of Rome's Project on the Predicament of Mankind. New York : Universe Books, 1972.

MILL, John Stuart. Principles of Political Economy with Some of their Applications to Social Philosophy. Vols. I \& II. London: John W. Parker, 1848. NASH, Roderick. American Environmentalism: Readings in Conservation History. New York: McGraw-Hill, 1990.

WORSTER, Donald. A River running West: the Life of John Wesley Powell. New York: Oxford University Press, 2000.

WORSTER, Donald. A Passion for Nature: the Life of John Muir. New York: Oxford University Press, 2008.

2 Trad. livre da autora: "But what are the odds of finding another nature, another hemisphere of such easy abundance? Zero". 